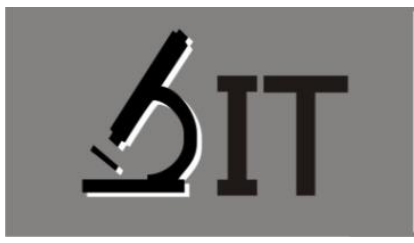

p-ISSN : 2597-8977

e-ISSN : $2597-8985$

Musyabirah*) Universitas Negeri Makassar

Abdul Mun'im Universitas Negeri Makassar

Sitti Rahma Yunus Universitas Negeri Makassar

*) Correspondence Author: musyabirahjalil@gmail.com
JIT 2 (1) (2018) 36-45

JURNAL IPA TERPADU

http://ojs.unm.ac.id/index.php/ipaterpadu

\section{PENGARUH MODEL PEMBELAJARAN KOOPERATIF TIPE TALKING STICKTERHADAP MOTIVASI DAN HASIL BELAJAR PESERTA DIDIK KELAS VIII SMP NEGERI 5 PALLANGGA}

Abstrak: Penelitian ini bertujuan untuk 1) mengetahui pengaruh model pembelajaran kooperatif tipe Talking Stick terhadap motivasi belajar peserta didik kelas VIII SMP Negeri 5 Pallangga dan (2) mengetahui pengaruh model pembelajaran kooperatif tipe Talking Stick terhadap hasil belajar peserta didik kelas VIII SMP Negeri 5 Pallangga. Jenis penelitian adalah eksperimen semu. Desain penelitian ini adalah pretest-posttest nonequivalent control group design. Populasi penelitian ini adalah peserta didik SMP Negeri 5 Pallangga yang terdiri atas 7 kelas (203 peserta didik). Pengambilan sampel menggunakan teknik double random sampling. Sampel penelitian yang digunakan 26 orang pada kelas eksperimen dan 26 orang pada kelas kontrol. Pengumpulan data dilakukan dengan menggunakan instrumen angket untuk mengukur motivasi dan instrumen tes hasil belajar yang berupa pilihan ganda untuk mengukur hasil belajar peserta didik. Data yang diperoleh dianalisis dengan menggunakan tehnik analisis statistik deskriptif dan analisis inferensial. Statistik deskriptif bertujuan untuk mengetahui tingkat pengkategorian pada motivasi dan hasil belajar. Hasil analisis inferensial dengan menggunakan uji-t motivasi belajar diperoleh nilai thitung 4,12 > ttabel 2,07. Dari hasil perhitungan ujit hasil belajar diperoleh thitung 6,77 > ttabel 2,07. sehingga Ho ditolak dan H1 diterima, dapat disimpulkan bahwa terdapat pengaruh model pembelajaran kooperatif tipe Talking Stick terhadap motivasi dan hasil belajar peserta didik kelas VIII SMP Negeri 5 Pallangga.

Kata Kunci: Talking Stick, Motivasi Belajar, Hasil Belajar.

Abstract: This study aims to 1) determine the effect of cooperative learning model Talking Stick the motivation of learners in grade VIII SMP Negeri 5 Pallangga and (2) the effect of cooperative learning model Talking Stick the learning outcomes of students of class VII I C MP Negeri 5 Pallangga. This type of research is a quasi experiment. The research design was pretest-posttest nonequivalent control group design. The population of this research is the students of SMP Negeri 5 Pallangga consisting of 7 classes (203 students). The research sample used 26 people in the class experiment and 26 people in the class control. The data were collected by using questionnaire instrument to measure motivation and test result of learning instrument which were multiple choice to measure learners' learning result. Data were analyzed using descriptive statistical analysis techniques and inferential analysis. Descriptive statistics aims to determine the level of categorization on motivation and learning outcomes. The result of inferential analysis using t-test learning motivation obtained $t_{\text {count }}$ of 4,12 $>t_{\text {table }} 2,07$. From the calculation of $t$-test study result obtained $\mathrm{t}_{\text {count }}$ is 6,77 $>\mathrm{t}_{\text {table }}$ is 2,07 so that $\mathrm{Ho}$ is reject and $\mathrm{H} 1$ accepted, so that it can be concluded that there are significant learning model 
cooperative type Talking Stick to the motivation and learning outcomes students class VIII SMP Negeri 5 Pallangga.

Keyword: Talking Stick, Motivation, Learning Outcomes.

\section{PENDAHULUAN}

Pembelajaran merupakan proses interaksi antara peserta didik, antara peserta didik dengan tenaga pendidik dan sumber belajar pada lingkungan belajar. Melalui proses pembelajaran, peserta didik dapat mengembangkan potensi dan karakternya sebagai hasil dari sinergi antara pendidikan yang berlangsung di sekolah, keluarga dan masyarakat. Dengan memberikan kesempatan, kemampuan peserta didik semakin lama akan semakin meningkat dalam bersikap, pengetahuan, dan keterampilan yang diperlukan dalam hidupnya dan untuk bermasyarakat, berbangsa serta berkontribusi dalam kesejahteraan hidup umat manusia (Permendikbud, 2014).

Setiap individu memiliki karakteristik yang berbeda dengan individu yang lainnya. Tidak bisa dipungkiri akan muncul keragaman karakteristik diantara peserta didik, baik latar belakang, minat, gaya belajar, maupun keragaman peserta didik dalam menyerap informasi materi pelajaran. Keragaman yang terjadi dalam suatu kelas adalah sesuatu yang tidak dapat dihindari oleh pendidik sebagai fasilitator pembelajaran. Seiring dengan perkembangan zaman, pendidik dituntut untuk kreatif dan inovatif dalam memilih dan mengembangkan metode pembelajaran. Tujuannya adalah agar pembelajaran dapat memenuhi kebutuhan belajar peserta didik dan memaksimalkan potensi belajar peserta didik.

Rendahnya hasil belajar IImu Pengetahuan Alam (IPA) merupakan dampak dari berbagai masalah yang muncul dalam pembelajaran. Permasalahan yang terlihat adalah kurangnya aktivitas peserta didik dalam mengikuti proses pembelajaran, khususnya mata pelajaran IPA. Peserta didik hanya bertindak sebagai pendengar, sehingga peserta didik pasif pada saat pembelajaran.

Berdasarkan hasil observasi yang dilakukan di SMP Negeri 5 Pallangga diperoleh informasi bahwa hasil belajar di SMP Negeri 5 Pallangga masih tergolong rendah. Hal ini dapat dilihat dari data nilai KKM (Kriteria Ketuntasan Minimal) yang diperoleh peserta didik. Nilai KKM yang ditetapkan sekolah SMP Negeri 5 Pallangga yaitu 70. Proses pembelajaran IPA masih kurang maksimal, hal ini terlihat dari proses pembelajaran yang berpusat pada pendidik. Model pembelajaran yang bersifat satu arah menjadikan peserta didik kurang bersemangat dan pasif selama mengikuti proses pembelajaran. Peserta didik kurang mengajukan pertanyaan-pertanyaan dan hanya menunggu perintah pendidik, serta kemampuan menggali informasi oleh peserta didik tidak dapat dikembangkan dengan baik dalam proses pembelajaran dan berpengaruh pada motivasi dan hasil belajar peserta didik.

Model pembelajaran sangat penting dalam suatu kegiatan pembelajaran. Kegiatan ini dirancang untuk mengikuti prinsip-prinsip pembelajaran. Dalam halini pendidik berpesan sebagai motivator yang seharusnya dapat memberikan stimulus bagi peserta didik demi terciptanya suatu kegiatan pembelajaran sehingga tujuan pembelajaran tersebut tercapai. Salah satu upaya yang dapat dilakukan oleh guru yaitu dengan menerapkan model pembelajaran di dalam kegiatan pembelajaran.

Model pembelajaran merupakan hal yang sangat penting dalam proses pembelajaran. Dengan menerapkan model pembelajaran yang tepat, pendidik akan mudah untuk memberikan stimulus kepada peserta didik, sehingga pembelajaran berpusat kepada peserta didik, bukan pada pendidik. Hal ini diperkuat oleh pernyataan UNESCO, bahwa "ada empat pilar pendidikan yang harus dipahami oleh pendidik dan peserta didik, yaitu learning to do, learning to know, learning to be, and learning to live together" (Munawaroh, dkk. 2012). 
Pembelajaran kooperatif tipe Talking Stick akan membantu peserta didik menguasai materi yang diajarkan oleh pendidik, khususnya pada materi sistem pencernaan pada manusia yang diajarkan pada semester ganjil kelas VIII SMP. Materi pokok sistem pencernaan pada manusia mengantarkan peserta didik untuk memahami konsep sistem pencernaan pada manusia, dimana topik ini membahas mengenai konsep sistem pencernaan pada manusia, fungsi makanan bagi tubuh manusia serta gangguan pada sistem pencernaan manusia.

Suasana belajar dengan menggunakan Talking Stick diharapkan mampu untuk menumbuhkembangkan potensi yang ada di dalam diri peserta didik dan mampu menmbuhkan keberanian untuk mengemukakan pendapat sehingga peserta didik dapat memahami materi pembelajaran dibandingkan peserta didik yang mendengarkan pendidik berbicara. Dengan begitu peserta didik tidak merasa jenuh ketika belajar dan memotivasi belajar pada diri peserta didik dapat ditingkatkan. Dengan demikian, diadakan penelitian untuk mengetahui pengaruh pengaruh model pembelajaran kooperatif tipe talking stick terhadap motivasi dan hasil belajar peserta didik pada materi pokok sistem pencernaan pada manusia kelas VIII SMP Negeri 5 Pallangga. Rumusan masalah yang digunakan pada penelitian ini yaitu, (1) Apakah terdapat pengaruh model pembelajaran kooperatif tipe Talking Stick terhadap motivasi belajar peserta didik pada materi pokok sistem pencernaan pada manusia kelas VIII SMPN 5 Pallangga?, (2) Apakah terdapat pengaruh model pembelajaran kooperatif tipe Talking Stick terhadap hasil belajar peserta didik pada materi pokok sistem pencernaan pada manusia kelas VIII SMPN 5 Pallangga?

Talking stick merupakan salah satu dari model pembelajaran kooperatif, dimana pembelajaran ini menggunakan tongkat sebagai giliran untuk berpendapat atau menjawab pertanyaan dari pendidik setelah peserta didik mempelajari materi pelajaran.

Pada dasarnya model pembelajaran ini mengajak peserta didik untuk belajar sambil bermain (Kurniasih \& Sani, 2015). Talking stick merupakan metode pembelajaran kelompok dengan bantuan tongkat. Metode pembelajaran ini akan membantu peserta didik dalam mengingat materi pembelajaran yang telah dipelajari dan menguji kemampuan yang telah mereka pada saat pendidik menyajikan materi pembelajaran. Sehingga dengan menggunakan metode pembelajaran ini menjadikan peserta didik aktif dalam proses pembelajaran (Huda, 2013)

Model pembelajaran Talking Stick secara umum bertujuan agar peserta didik mengetahui letak kesalahannya, sehingga peserta didik dapat mengerjakan yang serupa sesuai dengan petunjuk yang diberikan oleh pendidik. Pendidik sebaiknya segera mengoreksi dan memberikan evaluasi pada pekerjaan peserta didik. Dengan menggunakan cara ini, akan lebih efektif karena peserta didik dapat segera memperbaiki kesalahan dalam mengerjakan tugas (Suprijono, 2012).

Model pembelajaran Talking Stick terdapat Sembilan fase yang harus dilakukan, yaitu: (1) pendidik menyiapkan sebuah tongkat kira-kira panjangnya $20 \mathrm{~cm},(2)$ pendidik membagi peserta didik kedalam beberapa kelompok, (3) pendidik menyiapkan materi yang akan dipelajari, (4) pendidik memberi kesempatan kepada peserta didik untuk mempelajari materi, (5) peserta didik menutup buku yang telah dipelajari, (6) pendidik memberikan tongkat kepada peserta didik, pendidik memberikan pertanyaan kepada peserta didik yang memegang tongkat sampai sebagian besar peserta didik mendapat bagian menjawab pertanyaan dari peserta didik, (7) pendidik bersama peserta didik menyimpulkan materi yang telah dipelajari, (8) pendidik memberikan evaluasi/penilaian, (9) pendidik menutup pembelajaran (Huda, 2013).

Menurut Kurniasih \& Sani (2015), model pembelajaran Talking Stick memiliki beberapa kelebihan dan kekurangan, yaitu:

\section{Kelebihan}

1. Menguji kesiapan peserta didik dalam penguasaan materi pelajaran

2. Melatih membaca dan memahami cepat materi yang telah disampaikan

3. Agar lebih giat belajar, karena siswa tidak pernah tahu tongkat akan sampai pada gilirannya 


\section{Kekurangan}

Jika ada peserta didik yang tidak memahami pelajaran, peserta didik akan merasa gelisah dan kawatir ketika nanti giliran tongkat berada pada tangannya.

Menurut Hengky, 2006 (Siregar, 2015) keunggulan Talking Stick adalah pertanyaan fokus pada materi pelajaran, menguji kesiapan siswa, memotivasi keberanian dan keterampilan siswa, mengajarkan mengeluarkan pendapat sendiri agar siswa berpikir sendiri apa jawaban dari pertanyaan tersebut dan mengasah kemampuan dan pengalaman siswa.

\section{METODE}

Jenis penelitian ang digunakan dalam penelitian ini adalah Quasi eksperiment dengan menggunakan desain Preteset-Posttest nonequivalent control group design. Penelitian dilakukan di SMP Negeri 5 Pallangga. Populasi penelitian adalah seluruh peserta didik kelas VIII SMP Negeri 5 Pallangga tahun ajaran 2017/2018 yang terdiri dari tujuh kelas. Pemilihan sampel dilakukan dengan menggunakan teknik double randem sampling sehingga diperoleh dua kelas sampel yakni kelas $\mathrm{VIII}_{\mathrm{A}}$ sebagai kelas eksperimen dan VIII sebagai kelas kontrol. Tahapan pengumpulan data dalam penelitian ini adalah sebagai berikut:

1. Pengumpulan data mengenai motivasi belajar peserta didik dilakukan dengan pemberian angket sebanyak 30 item pertanyaan, yang dibuat berdasarkan indikator motivasi belajar peserta didik. Pengumpulan data dilakukan sebanyak dua kali yaitu sebelum dan setelah menerapkan model pembelajaran Talking Stick.

2. Pengumpulan daa hasil belajar kognitif peserta didik dilakukan dengan pemberian tes hasilbelajar kognitif yang dibuat dalam bentuk pilihan ganda. Pengumpulan data sebelum dan setelah menerapkan model pembelajaran Talking Stick.

3. Pengumpulan data lembar keterlakasanaan model merupakan angket yang diisi oleh pengamat untuk meninjau keterlakasanaan model pembelajaran yang diterapkan peneliti di kelas. Aspek-aspek yang dinilai oleh pengamat adalah ketersesuaian langkah-langkah sesuai sintaks model pembelajaran yang diterapkan di kelas. Setiap aspek diberi nilai dengan dua kategori yaitu YA = jika dilakukan oleh peneliti dan TIDAK= jika tidak dilakukam oleh peneliti. Setelah melakukan tehnik pengumpulan data, selanjutnya data akan dianalisis statistik deskriptif dan analisis statistik inferensial.

\section{HASIL DAN PEMBAHASAN}

\section{Hasil Penelitian}

Motivasi dan hasil belajar peserta didik pada kelas eksperimen dengan menggunakan model pembelajaran kooperatif tipe Talking Stick mengalami peningkatan lebih tinggi daripada kelas kontrol yang dibelajarkan dengan menggunakan model pembelajaran konvensional. Skor motivasi dan hasil belajar yang dimaksud adalah skor total hasil tes diperoleh peserta didik baik pada kelas ekperimen maupun kelas kontrol. 
Tabel 1. Statistik Data Motivasi Belajar Peserta didik Kelas Eksperimen dan Kelas Kontrol

\begin{tabular}{cccccc}
\hline \multirow{2}{*}{ No } & \multirow{2}{*}{ Statistik } & \multicolumn{2}{c}{ Kelas Eksperimen } & \multicolumn{2}{c}{ Kelas Kontrol } \\
\cline { 3 - 6 } & Pretest & Posttest & Pretest & Posttest \\
\hline 1 & Jumlah sampel & 26 & 26 & 26 & 26 \\
2 & Skor tertinggi & 98 & 117 & 98 & 115 \\
3 & Skor terendah & 87 & 100 & 87 & 98 \\
4 & Skor rata-rata & 93,65 & 109,07 & 93,11 & 105,92 \\
5. & Standar deviasi & 3,48 & 4,36 & 3,34 & 4,22 \\
\hline
\end{tabular}

Berdasarkan tabel diatas diperoleh bahwa skor tertinggi kelas eksperimen pada posttest adalah 117 dengan skor rata-rata 109,07 dan standar deviasi 4,36 dari jumlah peserta didik 26 orang. Sedangkan skor tertinggi kelas kontrol adalah 115 dengan skor rata-rata 105,92 dan standar deviasi 4,22 dari jumlah peserta didik 26 orang.

Tabel 2 Kategori Data Motivasi Belajar Peserta Didik Kelas Eksperimen dan Kelas Kontrol

\begin{tabular}{cccc}
\hline \multirow{2}{*}{ Interval Skor } & \multirow{2}{*}{ Kategori } & \multicolumn{2}{c}{ Jumlah } \\
\cline { 3 - 4 } & & Kelas Eksperimen & Kelas Kontrol \\
\hline $0-24$ & Sangat Rendah & 0 & 0 \\
$25-48$ & Rendah & 0 & 0 \\
$49-72$ & Sedang & 0 & 0 \\
$73-96$ & Tinggi & 0 & 0 \\
$97-120$ & Sangat Tinggi & 26 & 26 \\
\hline \multicolumn{2}{c}{ Jumlah } & $\mathbf{2 6}$ & $\mathbf{2 6}$
\end{tabular}

Berdasarkan Tabel diatas diperoleh bahwa data motivasi belajar peserta didik kelas eksperimen dan kelas kontrol sama-sama memperoleh skor dengan kategori sangat tinggi pada interval skor 97-120.

Tabel 3 Statistika Skor Hasil Belajar Peserta Didik Kelas Eksperimen dan Kelas Kontrol

\begin{tabular}{cccccc}
\hline \multirow{2}{*}{ No } & \multirow{2}{*}{ Statistik } & \multicolumn{2}{c}{ Kelas Eksperimen } & \multicolumn{2}{c}{ Kelas Kontrol } \\
\cline { 3 - 6 } & & Pretest & Posttest & Pretest & Posttest \\
\hline 1 & Jumlah sampel & 26 & 26 & 26 & 26 \\
2 & Skor tertinggi & 15 & 28 & 16 & 27 \\
3 & Skor terendah & 4 & 17 & 5 & 16 \\
4 & Skor rata-rata & 7,80 & 21,57 & 6,96 & 19,19 \\
5. & Standar deviasi & 2,99 & 3,05 & 3,02 & 2,92 \\
\hline
\end{tabular}

Berdasarkan tabel diatas, menunjukkan hasil belajar peserta didik kelas eksperimen dan kelas kontrol. Skor tertinggi yang diperoleh kelas eksperimen adalah 28 dengan skor rata-rata 21,57 dan standar deviasi 3,05 dari jumlah 26 orang peserta didik. Sedangkan skor tertinggi yang diperoleh kelas kontrol adalah 27 dengan skor rata-rata 19,19 dan standar deviasi 2,92 dari jumlah 26 orang peserta didik. 
Tabel 4. Kategori Data Hasil Belajar Peserta Didik Kelas Eksperimen dan Kelas Kontrol

\begin{tabular}{cccc}
\hline \multirow{2}{*}{ Interval Skor } & \multirow{2}{*}{ Kategori } & \multicolumn{2}{c}{ Jumlah } \\
\cline { 3 - 4 } & & Kelas Eksperimen & Kelas Kontrol \\
\hline $0-5$ & Sangat Rendah & 0 & 0 \\
$6-11$ & Rendah & 0 & 0 \\
$12-17$ & Sedang & 2 & 6 \\
$18-24$ & Tinggi & 15 & 18 \\
$25-30$ & Sangat Tinggi & 9 & 2 \\
\hline \multicolumn{3}{c}{ Jumlah } & $\mathbf{2 6}$ \\
\hline
\end{tabular}

Berdasarkan tabel diatas, diperoleh bahwa data hasil belajar peserta didik kelas eksperimen terdapat 2 orang peserta didik memperoleh skor dengan kategori sedang, 15 orang dengan ketegori tinggi dan 9 orang peserta didik yang memperoleh skor dengan kategori sangat tinggi. Sedangkan pada kelas kontrol terdapat 6 orang peserta didik memperoleh skor dengan kategori sedang 18 orang dengan kategori tinggi dan 2 orang peserta didik yang memperoleh skor dengan kategori sangat tinggi. Dengan demikian dapat disimpulkan bahwa hasil belajar kelas eksperimen lebih tinggi daripada hasil belajar kelas kontrol.

Tabel 5. Persentase Pencapaian Indikator Motivasi Belajar Peserta Didik

\begin{tabular}{|c|c|c|c|c|c|c|c|c|}
\hline \multirow[b]{2}{*}{ No } & \multirow[b]{2}{*}{ Indikator } & \multirow[b]{2}{*}{ No. Soal } & \multicolumn{3}{|c|}{ Eksperimen } & \multicolumn{3}{|c|}{ Kontrol } \\
\hline & & & Pre & Post & $\begin{array}{c}\text { Persentase } \\
(\%)\end{array}$ & Pre & Post & $\begin{array}{c}\text { Persentase } \\
(\%)\end{array}$ \\
\hline 1 & $\begin{array}{l}\text { Hasrat dan keinginan } \\
\text { berhasil }\end{array}$ & $\begin{array}{c}1,3,9,7,1 \\
3,29\end{array}$ & 52,08 & 61,14 & 10,87 & 51,45 & 57,81 & 7,63 \\
\hline 2 & $\begin{array}{l}\text { Dorongan dan } \\
\text { kebutuhan dalam } \\
\text { belajar }\end{array}$ & $\begin{array}{c}11,18,20 \\
5,15,17 \\
24\end{array}$ & 61,56 & 69,38 & 9,38 & 61,67 & 66,98 & 6,38 \\
\hline 3 & $\begin{array}{l}\text { Harapan dan cita-cita } \\
\text { masa depan }\end{array}$ & $\begin{array}{c}2,14,25 \\
26,27\end{array}$ & 40,73 & 48,75 & 9,63 & 42,39 & 46,86 & 5,38 \\
\hline 4 & $\begin{array}{l}\text { Penghargaan dalam } \\
\text { belajar }\end{array}$ & 6,30 & 15,83 & 20,42 & 5,5 & 14,69 & 20,31 & 6,75 \\
\hline 5 & $\begin{array}{l}\text { Kegiatan yang } \\
\text { menarik } \\
\text { belajar }\end{array}$ & $\begin{array}{c}8,10,19, \\
22,23 \\
28,4,21\end{array}$ & 49,69 & 56,44 & 8,09 & 49,70 & 55,76 & 7,27 \\
\hline 6 & $\begin{array}{l}\text { Adanya lingkungan } \\
\text { belajar yang kondusif }\end{array}$ & 12,16 & 15,63 & 18,85 & 3,88 & 16,04 & 18,44 & 2,86 \\
\hline
\end{tabular}

Berdasarkan tabel di atas menunjukkan bahwa hasil perhitungan pencapaian indikator tertinggi pada kelas eksperimen dengan indikator hasrat dan keinginan berhasil (10,87\%) dan pencapaian terendah pada indikator adanya lingkungan belajar yang kondusif (3,88\%). Sedangkan pada kelas kontrol pencapaian indikator tertinggi pada indikator adanya hasrat dan keinginan berhasil (7,63\%) dan pencapaian terendah pada indikator adanya lingkungan belajar yang kondusif (2,86\%). Berdasar data diatas, dapat disimpulkan bahwa hasil perhitungan persentase pencapaian indikator pada kelas eksperimen lebih tinggi dibandingkan persentase pencapaian indikator pada kelas kontrol. 
Tabel 6. Persentase Pencapaian Indikator Hasil Belajar Peserta Didik

\begin{tabular}{|c|c|c|c|c|c|c|c|c|}
\hline \multirow[b]{2}{*}{ No } & \multirow[b]{2}{*}{ Indikator } & \multirow[b]{2}{*}{ No. Soal } & \multicolumn{3}{|c|}{ Eksperimen } & \multicolumn{3}{|c|}{ Kontrol } \\
\hline & & & Pre & Post & $\begin{array}{c}\text { Persentase } \\
\text { (\%) }\end{array}$ & Pre & Post & $\begin{array}{c}\text { Persentase } \\
(\%)\end{array}$ \\
\hline 1 & \begin{tabular}{lr}
\multicolumn{2}{l}{ Membedakan antara } \\
saluran pencernaan \\
dan & kelenjar \\
pencernaan & sebagai \\
penyusun & sistem \\
pencernaan & pada \\
manusia &
\end{tabular} & $\begin{array}{c}1,2,3,4,5 \\
6,7,8\end{array}$ & 25,42 & 67,5 & 12,63 & 29,17 & 58,33 & 8,75 \\
\hline 2 & $\begin{array}{l}\text { Membandingkan } \\
\text { pencernaan mekanik } \\
\text { dan pencernaan } \\
\text { kimiawi }\end{array}$ & $\begin{array}{c}9,10,11 \\
12\end{array}$ & 19,17 & 69,17 & 15 & 26,67 & 60 & 10 \\
\hline 3 & $\begin{array}{l}\text { Menyebutkan } \\
\text { komponen- } \\
\text { komponen dasar } \\
\text { makanan }\end{array}$ & $\begin{array}{l}13.14 \cdot 15.1 \\
6.17 .18 \\
19\end{array}$ & 14,58 & 54,58 & 12 & 15,42 & 51,67 & 10,88 \\
\hline 4 & $\begin{array}{l}\text { Menjelaskan fungsi } \\
\text { makanan bagi tubuh } \\
\text { manusia }\end{array}$ & $20,21,22$ & 10,83 & 45,83 & 10,5 & 16,67 & 43,33 & 8 \\
\hline 5 & $\begin{array}{l}\text { Menyebutkan } \\
\text { contoh kelainan dan } \\
\text { penyakit pada sistem } \\
\text { pencernaan yang } \\
\text { biasa dijumpai dalam } \\
\text { kehidupan sehari- } \\
\text { hari }\end{array}$ & $\begin{array}{l}23,24,25 \\
26,27,28 \\
, 29\end{array}$ & 20,42 & 56,67 & 10,88 & 23,75 & 50 & 7,88 \\
\hline 6 & $\begin{array}{l}\text { Menjelaskan upaya } \\
\text { dalam mengatasi } \\
\text { kelainan dan } \\
\text { penyakit pada sistem } \\
\text { pencernaan }\end{array}$ & 30 & 50 & 66,67 & 5 & 50 & 50 & 0 \\
\hline
\end{tabular}

Berdasarkan tabel diatas, menunjukkan bahwa hasil perhitungan pencapaian indikator tertinggi pada kelas eksperimen yaitu membandingkan pencernaan mekanik dan pencernaan kimiawi (15\%) dan pencapaian terendah pada indikator menjelaskan upaya dalam mengatasi kelainan dan penyakit pada sistem pencernaan (5\%). Sedangkan pencapaian tertinggi pada kelas kontrol yaitu indikator menyebutkan komponen-komponen dasar makanan (10,88\%) dan pencapaian terendah pada indikator menjelaskan upaya dalam mengatasi kelainan dan penyakit pada sistem pencernaan (0\%). Berdasarkan data diatas, maka dapat disimpulkan bahwa persentase pencapaian indikator pada kelas eksperimen lebih tinggi dibandingkan dengan persentase pencapaian indikator pada kelas kontrol.

Uji normalitas yang digunakan pada penelitian ini adalah uji chi-kuadrat. Pada kelas eksperimen yang dibelajarkan menggunakan model pembelajaran Talking Stick terhadap motivasi belajar diperoleh nilai $X^{2}{ }_{\text {hitung }}=3,622$. Sedangkan pada kelas kontrol yang dibelajarkan dengan model pembelajaran langsung diperoleh 4,017. Perhitungan untuk nilai $X^{2}$ tabel $=t(0,05)(5)=11,070$. Pada kelas eksperimen yang dibelajarkan menggunakan model pembelajaran Talking Stick terhadap hasil belajar diperoleh nilai $X^{2}$ hitung $=5,603$. Sedangkan pada kelas kontrol yang dibelajarkan dengan 
model pembelajaran langsung diperoleh 6,220 Perhitungan untuk nilai $X^{2}$ tabel $=t(0,05)(5)=11,070$. Dengan membandingkan data diatas, dapat dinyatakan bahwa $X^{2}$ hitung $<X^{2}$ tabel, hal ini berarti data pada kelas eksperimen dan kelas kontrol terdistribusi normal.

Uji homogenitas digunkan untuk mengetahui apakah kedua kelompok data yang diteliti berasal dari popoulasi yang homogen atau tidak. Pada pengujian homogenitas terhadap motivasi data diperoleh $F_{\text {hitung }}=1,04$. Sedangkan pengujian homogenitas pada hasil belajar data diperoleh $F_{\text {hitung }}=1,64$. Pada taraf nyata $\alpha=0,05$, maka $F_{\text {tabel }}=F_{(0,05)(25 / 25)}=3,42$. Karena $F_{\text {hitung }}<F_{\text {tabel, }}$ maka dapat dinyatakan bahwa data dari kedua kelompok tersebut adalah homogen.

Pengujian hipotesis dilakukan dengan menggunakan uji-t. hasil uji-t pada motivasi belajar diperoleh data $t_{\text {hitung }}=4,12, t_{\text {tabel }}=2,07$. Hasil analisis data diperoleh bahwa nilai $t_{\text {hitung }}>t_{\text {tabel }}$ maka $H_{0}$ ditolak dan $\mathrm{H}_{1}$ diterima. Sedangkan uji-t hasil belajar, data diperoleh $\mathrm{t}_{\text {hitung }}=6,77$, nilai $t_{\text {tabel }}=2,07$. Hasil analisis data diperoleh bahwa nilai $t_{\text {hitung }}>t_{\text {tabel }}$ maka $\mathrm{H}_{\mathrm{o}}$ ditolak dan $\mathrm{H}_{1}$ diterima. Oleh karena itu, dapat disimpulkan bahwa terdapat pengaruh model pembelajaran kooperatif tipe talking stick terhadap motivasi dan hasil belajar peserta didik kelas VIII SMP Negeri 5 Pallangga.

\section{Pembahasan}

Berdasarkan penelitian yang telah dilakukan pada materi sistem pencernaan pada manusia menunjukkan bahwa motivasi dan hasil belajar peserta didik yang dibelajarkan dengan model pembelajaran kooperatif tipe Talking Stick lebih tinggi dibandingkan dengan hasil belajar pada model pembelajaran konvensional. Hasil analisis deskriptif diperoleh bahwa motivasi belajar peserta didik kelas eksperimen dan kelas kontrol di SMP Negeri 5 Pallangga. Skor tertinggi kelas eksperimen pada posttest adalah 117 dengan skor rata-rata 109,07 dan standar deviasi 4,36 dari jumlah peserta didik 26 orang. Sedangkan skor tertinggi kelas kontrol adalah 115 dengan skor ratarata 105,92 dan standar deviasi 4,22 dari jumlah peserta didik 26 orang. Sedangkan berdasarkan analisis deskriptif hasil belajar diperoleh Skor tertinggi yang diperoleh kelas eksperimen adalah 28 dengan skor rata-rata 21,57 dan standar deviasi 3,05 dari jumlah 26 orang peserta didik. Sedangkan skor tertinggi yang diperoleh kelas kontrol adalah 27 dengan skor rata-rata 19,19 dan standar deviasi 2,92 dari jumlah 26 orang peserta didik. Hal ini menunjukkan bahwa rata-rata hasil belajar kelas eksperimen masih lebih unggul dibandingkan dengan rata-rata hasil belajar kelas kontrol. Oleh karena itu, dapat disimpulkan bawa model pembelajaran kooperatif tipe Talking Stick berpengaruh terhadap motivasi dan hasil belajar peserta didik kelas VIII SMP Negeri 5 Pallangga. Hasil penelitian motivasi didukung oleh Janayanti, dkk (2017) Pada pengujian hipotesis, diperoleh F hitung $=10,703$ dengan sig $=0,001$ sedangkan taraf signifikansi $(\alpha)$ yang diterapkan adalah $5 \%(0,05)$. Sehingga $a>\operatorname{sig}(0,05>0,001)$. Hal ini menunjukkan bahwa motivasi belajar peserta didik yang dibelajarkan dengan model pembelajaran Talking Stick lebih tinggi dibandingkan motivasi belajar peserta didik yang tidak dibelajarkan dengan model pembelajaran Talking Stick.

Penelitian hasil belajar juga didukung oleh hasil penelitian Budiantini, dkk (2017), pada pengujian hipotesis, diperoleh $t_{\text {hitung }} 3,256>t_{\text {tebel }} 1,997$ dengan $\alpha=5 \%(0,05)$. Disimpulkan bahwa hasil belajar peserta didik yang dibelajarkan dengan model pembelajaran Talking Stick lebih tinggi

dibandingkan hasil belajar peserta didik yang dibelajarkan dengan model pembelajaran konvensional.

\section{KESIMPULAN}

Berdasarkan hasil penelitian yang telah dilakukan dapat disimpulkan sebagai berikut:

1. Motivasi belajar IPA peserta didik kelas VIII (eksperimen) yang dibelajarkan dengan menggunakan model pembelajaran Talking Stick berdasarkan analisis deskriptif diperoleh 
skor rata-rata 0,60 dan standar deviasi 0,122. Pada kelas VIII (kontrol) yang dibelajarkan dengan menggunakan model pembelajaran konvensional berdasarkan analisis deskriptif diperoleh skor rata-rata 0,46 dan standar deviasi 0,125. Berdasarkan hasil uji t diperoleh nilai $\mathrm{t}$ hitung $=4,12>\mathrm{t}$ tabel $=2,07$. Ini membuktikan bahwa model pembelajaran Talking Stick memiliki pengaruh yang signifikan terhadap motivasi belajar peserta didik kelas VIII SMP Negeri5 Pallangga.

2. Hasil belajar IPA peserta didik kelas $\mathrm{VIII}_{\mathrm{A}}$ (eksperimen) yang dibelajarkan dengan menggunakan model pembelajaran Talking Stick berdasarkan analisis deskriptif diperoleh skor rata-rata 0,67 dan standar deviasi 0,078. Pada kelas VIII (kontrol) yang dibelajarkan dengan menggunakan model pembelajaran konvensional berdasarkan analisis deskriptif diperoleh skor rata-rata 0,54dan standar deviasi 0,061. Berdasarkan hasil uji t diperoleh nilai $\mathrm{t}$ hitung $=6,77>\mathrm{t}$ tabel $=2,07$. Ini membuktikan bahwa model pembelajaran Talking Stick memiliki pengaruh yang signifikan terhadap hasil belajar peserta didik kelas VIII SMP Negeri 5 Pallangga.

\section{DAFTAR PUSTAKA}

Budiantini, Suartama, \& Japa. (2017). Pengaruh Model Pembelajaran Koopertaif tipe Talking Stick Terhadap Hasil Belajar IPA Siswa Kelas V SD. e-journal PGSD Universitas Pendidikan Ganesha. Mimbar PGSD. Vol.5, No.2. Tahun 2017. Diakses pada tanggal 11 November 2017.

Huda, M. (2013). Model-Model Pengajaran dan Pembelajaran. Yogyakarta: Pustaka Pelajar.

Janayanti, F., Parmiti, P., \& Gading, K. (2017). Pengaruh Model Pembelajaran Kooperatif Tipe Talking Stick dan Motivasi Berprestasi Terhadap Hasil Belajar IPS Siswa Kelas V SD. e-journal PGSD Universitas Pendidikan Ganesha. Mimber PGSD Vol.5, No.2, Tahun. 2017. Diakses pada tanggal 8 November 2017

Kurniasih, I. \& Sani, B. (2015). Ragam Pengembangan: Model Pembelajaran Untuk Peningkatan Profesionalitas Guru. Jakarta: Kata Pena

Munawaroh, R., Subali, B., Sopyan, A. (2012). Penerapan Model Project Based Learning dan Kooperatif Untuk Membangun Empat Pilar Pembelajaran Siswa SMP. Unnes Physics Education Journal. ISSN No 2257-6935. Diakses pada tanggal 9 November 2017

Permendikbud. (2014). Pedoman Pelaksanaan Pembelajaran. Jakarta: Mendikbud Republik Indonesia..

Siregar, S. (2015). Pengaruh Model Pembelajaran Talking Stick Terhadap Hasil Belajar dan Aktivitas Visual Siswa Pada Konsep Sistem Indra. Jurnal Biotik. ISSN: 2337-9812. Vol.3, No.2, Tahun 2015. Diakses pada tanggal8 November 2017

Suprijono, A. (2012). Cooperative Learning Teory \& Aplikasi Paikem. Yogyakarta: Pustaka Pelajar. 


\section{Musyabirah}

Mahasiswa Program Studi Pendidikan IPA FMIPA UNM, aktif melakukan penelitian pada bidang Pendidikan IPA, dapat dihubungi melalui pos-el: musyabirahjalil@gmail.com

\section{Abdul Mun'im}

Dosen Program Studi Pendidikan IPA FMIPA UNM, aktif melakukan penelitian pada bidang Pendidikan IPA.

\section{Sitti Rahma Yunus}

Dosen Program Studi Pendidikan IPA FMIPA UNM, aktif melakukan penelitian pada bidang Pendidikan IPA. 